\title{
EVALUATION OF MICROBIAL POTENTIAL AND RIPENING BEHAVOIUR OF PRECLIMACTERIC BANANAS FOLLOWING GAMMA IRRADIATION
}

\author{
AVALIAÇÃO DO POTENCIAL MICROBIANA E AMADURECEM \\ COMPORTAMENTO DE BANANAS PRECLIMACTERIC SEGUINTE IRRADIAÇÃO \\ GAMA
}

\author{
"Roheena ABDULLAH ${ }^{1}$; Hina QAISER ${ }^{1}$; Adeen FAROOQ ${ }^{1}$; Afshan KALEEM" ${ }^{1}$; \\ Mehwish IQTEDAR ${ }^{1}$; Mahwish AFTAB ${ }^{1}$; Shagufta NAZ ${ }^{1}$ \\ 1. Department of Biotechnology Lahore College for Women University, Lahore, Pakista. "roheena_abdullah@yahoo.com
}

\begin{abstract}
The current study was carried out to evaluate the effects of gamma irradiation on the epiphytic microflora and ripening process of the green Dwarf Cavendish bananas harvested at the three-quarter stage of the maturity. The mature green bananas were irradiated using Cobalt-60 as the source of irradiation at different dosages of $0.5,0.75$ and $1.0 \mathrm{kGy}$. The mean life of both the experimental and control group of fruits was analyzed under ambient conditions. For all the treatments the microbial potential, the decay percent and the ripening behavior of the fruits were recorded. Results revealed that the applied radiation doses reduced the decay incidence, delayed ripening process and greatly inhibit the microbial growth (total bacterial and fungal count) thereby enhancing the shelf life of bananas. Irradiation dose of $1.0 \mathrm{kGy}$ was found to be the most effective dose to positively maintain the stored bananas under ambient conditions. The mean life of bananas was extended by 14 days. The identification of the enteric bacteriaeaceae through API 20 E strips revealed the presence of Shigella sonnie on the fruit surface along with Escherichia coli and a nonfermentor spp. The dominant spoilage causing fungi identified were Aspergillus niger, Aspergillus flavus, Collotrichum musae, Fusarium oxysporum,Mucor spp, Lasiodiplodia theobromea and Rhizopus stolonifer.
\end{abstract}

KEYWORDS: Banana. Gamma irradiation. Microflora. Shelf life.

\section{INTRODUCTION}

Horticulture crops hold eminent importance of their high return per unit time and area. However, a substantial amount of postharvest wastage of these produces take place around the world that is responsible for the reduction of profits thus subsequently promoting food insecurity ( MASHAU et al., 2012). Worldwide post harvest losses of fruits and vegetables may reach up to 30 to $40 \%$ and even much higher in some developing nations ( ZAMAN et al., 2007). Reducing these post harvest losses is vital; ensuring that sufficient food, both in quantity and in quality is available to every inhabitant in our planet. One of the primary factors that can be held accountable for the losses is the microbiological decay. While passing from farm to the table the fresh produce is rendered available to potential microbial contamination at every step including cultivation, harvesting, transporting, packaging, storage and selling it to the final destination i.e. the consumer ( HASSAN et al., 2004). Consumers demand to use those fresh fruits and vegetables which are bacteriologically safe ( POSTMASTER et al., 1997). The food spoilage and contamination due to microbes and pathogens presents a serious risk in food safety. The Centre for Disease Control and Prevention stated that 76 million cases of food borne illness occur each year ( FIELDING, 2007). Incidences with identified etiology were essentially of bacterial origin demonstrating that the analysis of microbial load on the surfaces of raw fruits and vegetables is requisite.

Banana is grown in tropical regions of the world where the banana sector plays a key role in international trade. It stands at fourth place among the world's most important crops after rice, wheat and maize in terms of gross value production ( NELSON et al., 2006). Banana is highly perishable commodity due to its high water content and is therefore liable to many diseases, especially fungal infection. Being a climacteric fruit it exhibits high respiration rate ( LIU et al., 1999). The endogenous ethylene induces ripening making it strenuous to market the product in more distant localities. The short shelf life is the primary obstacle in exporting bananas( ZAMAN, PAUL, ALAM, IBRAHIM; HASSAN, 2007). Three main events occur after the banana fruit is harvested namely the preclimacteric phase, the ripening phase and the senescent phase. Ripening makes the fruit edible and comprises the most crucial phase in their life both physiologically and commercially. The preclimacteric period also referred to as the "green life" however is of extreme importance to the ripeners and importers as banana is transported before it is ripened. This period is 
characterized by low basal respiration rate and almost undetectable levels of ethylene production by the mature green fruit both. The longest practical preclimacteric period is desired for delaying the ripening and in turn enhancing the shelf life of banana ( SURENDRANATHAN, 2005).

The food irradiation, also authorized by WHO to increase food safety, plays a positive role in preserving the quality and mean life of fruits and vegetables. Gamma radiations have been proven to be energetically more powerful than the x-rays ( FAN; SOMMERS, 2012). Fruits are routinely irradiated around the globe with a purpose of delaying the ripening by altering the physiological processes in plant tissues ( FOLLETT; WEINERT, 2009). The maximum dose of ionizing radiation approved by the United States that can be applied to fresh fruits and vegetables for retarding growth, maturity and disinfestation is $1.0 \mathrm{kGy}$ ( MILLER, 2006). Ionizing radiation holds great potential for extending the shelf life of food commodities as it can eliminate pathogenic bacteria, disinfest fresh fruits and vegetables as a postharvest quarantine treatment and reduce or eliminate microorganisms. This technique has advantages over other techniques because gamma radiation presents effective and homogeneous penetration power in the tissue, requires a relatively short radiation time and does not increase the temperature of the fruit ( DIONÍSIO et al., 2009).

The longer shelf lives improve the trade opportunities between nations by extending time constraints under which fresh produce must be delivered to more distant geographic markets or by allowing the use of slower and less expensive modes of transportation. The current study was carried out to evaluate the effects of gamma irradiation on the epiphytic microflora and ripening process of the green Dwarf Cavendish bananas harvested at the three-quarter stage of the maturity.

\section{MATERIAL AND METHODS}

\section{Sample collection and gamma irradiation}

Green banana fruits (Musa sapientum cultivar 'Dwarf Cavendish'), harvested at color index no. 1 when the fruit had developed to a full threequarter grade, were obtained from the local market of Lahore. The dealer was requested to make sure that the selected samples for all experiments were taken from the third hand in each bunch from the same plantation. Hands were separated into clusters of five to six fingers. The fruits were sealed in cellophane bags, divided in control and experimental groups labeled indicating the doses of radiation to be applied. The experimental group was subjected to gamma radiation at Pakistan Radiation Services, Lahore, Pakistan using Cobalt-60 as the source at the dose rate of $60 \mathrm{~Gy} / \mathrm{hr}$. After irradiation, the fruits were stored in a dry place under ambient conditions. The fruits from each hand were then carefully detached and evaluated for the different parameters. Bananas were observed after every 2 days interval for their organoleptic properties and 7 days interval for microbial load till 21 days.

\section{Microbiological studies}

The bananas were cut carefully using pre sterilized knives to detach them from the hands. Serial dilution method was used for the isolation of microorganisms. The fruits (one banana fruit/per hand/treatment/rep) were shaken thoroughly for 20 min in $300 \mathrm{ml}$ of sterile saline water and serial dilutions were made out of this. $100 \mu \mathrm{l}$ of each dilution was transferred in to the sterilized petri plates containing Nutrient agar (for non-fastidious bacterial isolation), MacConkey agar (for Gramnegative enteric bacilli isolation) SalmonellaShigella agar (for Salmonella spp. and Shigella spp. isolation) and Potato Dextrose agar (for fungi isolation). The plates were then incubated at $37^{\circ} \mathrm{C}$ for 24 hours and at $30^{\circ} \mathrm{C}$ for 48 hours for bacterial and fungal growth respectively. Total viable count of bacteria and fungi were calculated according to Mohamed and MAhmoud (2010). Color, texture, margins, elevation, surface characteristics, consistency and optical properties, Gram and Endospore staining of the bacteria was performed. The API-20E test kit was used for the identification of enteric bacteria. Fungal species were identified on the basis micro and macroscopic characteristics using Methylene Blue as mounting technique.

\section{Fruit quality analysis Peel color}

The color of the banana peel was monitored by comparison with a color scale developed for banana ripening by Loeseck (1950). The scale ranged from 1 to 7 , with values representing: (1) green (2) traces of yellow (3) more green than yellow (4) more yellow than green (5) yellow with green endings (6) completely yellow (7) yellow with slight brown specks and (8) yellow with more brown specks.

\section{Pulp-to-peel ratio}

The pulp-to-peel ratio was determined by weighing the parts of individual samples. The results were expressed as the weight percentage of 
pulp relative to the peel according to Gloria and Adão (2013)

Pulp to Peel ratio $=\frac{\text { pulp weight }}{\text { peel weight }}$

\section{Decay Assessment}

The decay of the banana fruits during storage was recorded and based on visual inspection of each fruit for infection and their percent decay was observed (Gihan, 2010). In this regard, infected fruits were arranged into the following five categories: $0=$ superficial fleck (no decay), $1=1$ $24 \%$ of the surface decayed, $2=25-49 \%$ of the surface decayed, $3=50-74 \%$ of the surface decayed and $4=75 \%$ or more of the surface decayed. The decay index for each treatment was calculated by the following formula.

Decay Index $=$ Sum (Number of fruits per category $x$ Category number) / Total number of infected fruits) $\times 100$

Severity of Index $\%=$ DI/ $4 \times 100$

\section{Sensory evaluation using 9-point hedonic scale}

The marketable bananas were peeled and observed for the incidence of decaying after every week. The sensory qualities of control and irradiated banana samples were evaluated by using 9-point Hedonic scale. Acceptance testing was carried out to determine how much each sample was liked based on 9-point Hedonic scale for a set of attributes: taste, flavour, color and appearance acceptance where $1=$ like extremely and $9=$ dislike extremely (Stone et al., 2012).

\section{Statistical analysis}

The results were validated by Costat 6.4 using completely randomized block design and mean values were compared using Duncan's New Multiple Range test at $\mathrm{p} \leq 0.05$. The standard deviation and mean square error of replicates from mean value was also found out.

\section{RESULTS}

\section{Decay Assessment}

Table 1 shows the impact of gamma radiation on decay percent and shelf life enhancement of mature green bananas kept under room temperature. The positive effect of gamma radiation to lower the decay incidence so that the shelf life could be extended depended upon the level of the applied doses. No decay percent was observed for both the irradiated and non irradiated fruits upto 14 days of storage. After two weeks the non irradiated bananas started to deteriorate and at the end of the third week they were completely decayed. However, the irradiated fruits remained free of any such incidence for that period of time. Once the fruits irradiated at 0.5 and $0.75 \mathrm{kGy}$ reached the seventh stage of ripening after 21 days they also showed signs of decay which progressed with the passage of time. The dose of $1.0 \mathrm{kGy}$ was found to be the superior one for controlling the decay percent and injury as the fruits exposed to that dose remained healthy for upto 28 days.

Table 1. Impact of gamma radiation on decay percent of mature green bananas kept under room temperature

\begin{tabular}{|c|c|c|c|c|c|c|c|c|c|c|c|c|c|c|c|}
\hline \multirow{2}{*}{$\begin{array}{c}\text { Radiation } \\
\text { Doses (kGy) }\end{array}$} & \multicolumn{15}{|c|}{ Days of Storage } \\
\hline & 0 & 2 & 4 & 6 & 8 & 10 & 12 & 14 & 16 & 18 & 20 & 22 & 24 & 26 & 28 \\
\hline & 0 & 0 & 0 & 0 & 0 & 0 & 0 & 0 & 1 & 2 & 3 & 4 & $\mathrm{D}$ & $\mathrm{D}$ & $\mathrm{D}$ \\
\hline 0.5 & 0 & 0 & 0 & 0 & 0 & 0 & 0 & 0 & 0 & 0 & 0 & 0 & 1 & 2 & 3 \\
\hline 0.75 & 0 & 0 & 0 & 0 & 0 & 0 & 0 & 0 & 0 & 0 & 0 & 0 & 0 & 0 & 1 \\
\hline 1.0 & 0 & 0 & 0 & 0 & 0 & 0 & 0 & 0 & 0 & 0 & 0 & 0 & 0 & 0 & 0 \\
\hline
\end{tabular}

* Decayed; $0=$ superficial fleck (no decay), $1=1-24 \%$ of the surface decayed , $2=25-49 \%$ of the surface decayed , $3=50-74 \%$ of the surface decayed , $4=75 \%$ or more of the surface decayed

\section{Pulp to peel ratio}

Table 2 depicts the changes in the pulp to peel ratio in banana fruits at different doses of gamma radiation during ripening under room temperature. Pulp to peel ratio is regarded as a good and suitable index of ripening of banana fruits. The ratio always increases in response to ripeness (i.e peel color score). So, the ratio escalated for both the treated and untreated fruits as the ripening process continued. However, the rate of increase for the irradiated and non irradiated fruits was different. The untreated bananas attained the seventh stage of ripening within 14 days of storage. In comparison to that the treated fruits clearly had the ripening process delayed which was manifested in the form of slow increase in peel to pulp ratio and in turn the change from green to yellow pigmentation in the peel. The fruits exposed to the lowest doses of 0.5 $\mathrm{kGy}$ and $0.75 \mathrm{kGy}$ almost ripened one after another reaching the sixth stage of ripening in about three weeks. However, the dose of $1.0 \mathrm{kGy}$ was the most effective one in inhibiting the ripening process for the longest period of time in bananas. The fruits 
receiving this dose were found to be still at fifth

stage of ripening by the end of the 21 days period.

Table 2. Changes in pulp to peel ratio in banana fruits at different doses of gamma radiation during ripening under room temperature

\begin{tabular}{|c|c|c|c|c|c|c|c|c|}
\hline \multirow[b]{3}{*}{$\begin{array}{l}\text { Radiation Doses } \\
\quad(\mathrm{kGy})\end{array}$} & \multirow{3}{*}{$\begin{array}{l}\text { Parameters } \\
\text { Peel Colour }\end{array}$} & \multicolumn{7}{|c|}{ Stages of ripening } \\
\hline & & 1 & 2 & 3 & 4 & 5 & 6 & 7 \\
\hline & & $\begin{array}{l}\text { All } \\
\text { green }\end{array}$ & $\begin{array}{l}\text { Green } \\
\text { with a } \\
\text { trace of } \\
\text { yellow }\end{array}$ & $\begin{array}{l}\text { More } \\
\text { green } \\
\text { than } \\
\text { yellow }\end{array}$ & $\begin{array}{l}\text { More } \\
\text { yellow } \\
\text { than } \\
\text { green }\end{array}$ & $\begin{array}{l}\text { Yellow } \\
\text { with a } \\
\text { trace of } \\
\text { green }\end{array}$ & $\begin{array}{c}\text { All } \\
\text { yellow }\end{array}$ & $\begin{array}{c}\text { All } \\
\text { yellow } \\
\text { with } \\
\text { specks }\end{array}$ \\
\hline \multirow[t]{2}{*}{0} & $\begin{array}{c}\text { Day of } \\
\text { Analysis }\end{array}$ & $1^{\text {st }}$ & $3^{\text {rd }}$ & $5^{\text {th }}$ & $7^{\text {th }}$ & $9^{\text {th }}$ & $11^{\text {th }}$ & $13^{\text {th }}$ \\
\hline & $\begin{array}{l}\text { Pulp to peel } \\
\text { ratio }\end{array}$ & 0.89 & 1.13 & 1.35 & 1.71 & 2.1 & 2.5 & Ripened \\
\hline \multirow[t]{2}{*}{0.5} & $\begin{array}{c}\text { Day of } \\
\text { analysis }\end{array}$ & $1^{\text {st }}$ & $5^{\text {th }}$ & $9^{\text {th }}$ & $13^{\text {th }}$ & $17^{\text {th }}$ & $21^{\mathrm{st}}$ & $25^{\text {th }}$ \\
\hline & $\begin{array}{l}\text { Pulp to peel } \\
\text { ratio }\end{array}$ & 0.78 & 1.11 & 1.30 & 1.57 & 2.01 & 2.43 & Ripened \\
\hline \multirow[t]{2}{*}{0.75} & $\begin{array}{c}\text { Day of } \\
\text { Analysis }\end{array}$ & $1^{\mathrm{st}}$ & $5^{\text {th }}$ & $9^{\text {th }}$ & $13^{\text {th }}$ & $17^{\text {th }}$ & $21^{\mathrm{st}}$ & $25^{\text {th }}$ \\
\hline & $\begin{array}{l}\text { Pulp to peel } \\
\text { ratio }\end{array}$ & 0.80 & 1.12 & 1.24 & 1.49 & 1.99 & 2.54 & Ripened \\
\hline \multirow[t]{2}{*}{1.0} & $\begin{array}{c}\text { Day of } \\
\text { analysis }\end{array}$ & $1^{\mathrm{st}}$ & $6^{\text {th }}$ & $11^{\text {th }}$ & $16^{\text {th }}$ & $21^{\mathrm{st}}$ & $26^{\text {th }}$ & $31^{\text {th }}$ \\
\hline & $\begin{array}{l}\text { Pulp to peel } \\
\text { ratio }\end{array}$ & 0.81 & 0.98 & 1.08 & 1.51 & 1.93 & 2.30 & Ripened \\
\hline
\end{tabular}

\section{Sensory evaluation using 9 point hedonic scale}

Significance for consumer acceptance was carried out to evaluate the significance of attributes for both radiated and un-irradiated samples by using 9-point Hedonic scale (Figure 1 (a) and (b)). The consumer acceptance for radiated sample was found to be more as compared to un-irradiated bananas.
The characterization of trends of sensory qualities was also done by using sample size of 15 trained panelists. It was found that irradiated samples were superior in quality as compared to control samples. The quality of un-irradiated bananas was masked by changes in color of peel and rapid ripening rendering them less acceptable.

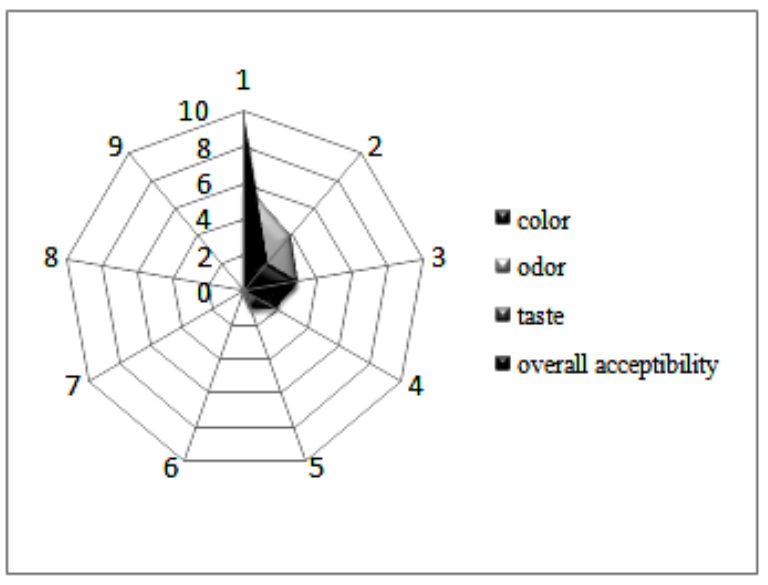

(a)

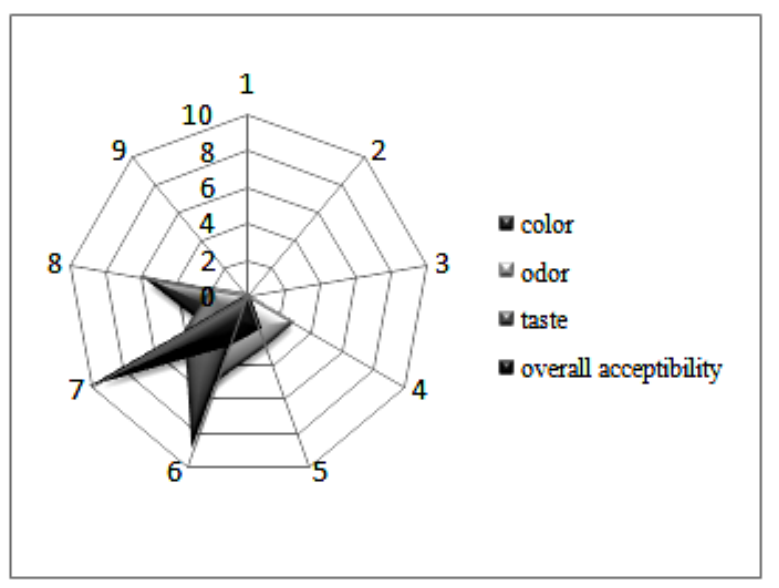

(b)

$* 1=$ extremely like, $9=$ extremely dislike. (trained panel members, $n=15$ )

Figure 1. Sensory evaluation for qualities like color, taste, odor and overall acceptance (a) irradiated samples (b) unirradiated samples 
Total viable bacterial count

\section{Enumeration of bacteria on Nutrient agar}

The Figure 2a depicted the significant effect of applied gamma radiation doses on total viable bacterial count of banana fruits stored at room temperature. In this regard the control group of banana fruits exhibited initial bacterial count of 13.0 $\times 10^{4} \mathrm{cfu} / \mathrm{g}$ after the first week of storage on nutrient agar medium. This count reached up to $32.5 \times 10^{4}$ $\mathrm{cfu} / \mathrm{g}$ during the next week when the bananas ripened to complete maturity. Different gamma radiation doses employed proved to be effective in reducing the total viable bacterial count to different extents with highest reduction observed at the highest dose of $1.0 \mathrm{kGy}$. The initial counts obtained for the doses of $0.5 \mathrm{kGy}, 0.75 \mathrm{kGy}$ and $1.0 \mathrm{kGy}$ were $5.2 \times 10^{4}, 3.5 \times 10^{4}$ and $1.9 \times 10^{4} \mathrm{cfu} / \mathrm{g}$ respectively. The bacterial count increased gradually with progressive weeks in case of irradiated bananas as well but remained low in comparison to the control banana fruits. After three weeks of storage the highest dose of $1.0 \mathrm{kGy}$ registered the total viable bacterial count of $10.4 \times 10^{4} \mathrm{cfu} / \mathrm{g}$ that was even less than the one for the control bananas after first week of storage. The effects of all the treatments on total viable bacterial count vary significantly from each other at $p \leq 0.05$. The bacteria were mainly gram positive rods but a few gram negative rods and gram positive cocci were also observed.

\section{Enumeration and identification of bacteria on Salmonella-Shigella agar}

The figure $2 b$ reveals the repressing effect of gamma irradiation on the bacterial growth on banana surface as observed on SS agar. There was a marked difference observed between the bacterial load of control and irradiated group of bananas. The control group harbored the initial total viable bacterial count of $8.6 \times 10^{4} \mathrm{cfu} / \mathrm{g}$ which increased up to $16.8 \times 10^{4} \mathrm{cfu} / \mathrm{g}$ by the end of the second week of storage. Again the irradiated group of banana's showed much less total viable bacterial count than the control one and this effect was more evident with the increase in the applied doses of gamma radiation. In relation to that the banana fruits irradiated at $0.5 \mathrm{kGy}, 0.75 \mathrm{kGy}$ and $1.0 \mathrm{kGy}$ had an initial total viable bacterial count of $3.2 \times 10^{4}, 1.6 \times$ $10^{4}$ and $6.0 \times 10^{4} \mathrm{cfu} / \mathrm{g}$ respectively. The lowest reduction was achieved by $1.0 \mathrm{kGy}$ as the bananas irradiated at that particular dose gave a total viable bacterial count of $7.8 \times 10^{4} \mathrm{cfu} / \mathrm{g}$ after three weeks in storage The effects of all the treatments on total viable bacterial count vary significantly from each other at $\mathrm{p} \leq 0.05$.No Salmonella colonies were observed from the testing of both the control and irradiated banana fruit samples indicating their complete absence on the fruit surface. However, colonies of Escherichia coli and Shigella were seen on the SS plates of control and irradiated banana samples.

\section{Enumeration and identification of bacteria on MacConkey agar}

The Figure 2c shows the total viable bacterial count of the irradiated and control group of bananas observed on MacConkey agar. The controls showed higher values than the irradiated ones. The control banana samples had an early total viable bacterial count of $3.9 \times 10^{4} \mathrm{cfu} / \mathrm{g}$ whereas banana samples irradiated at $0.5 \mathrm{kGy}$ and $0.75 \mathrm{kGy}$ exhibited a reduction level with total viable bacterial count of $2.3 \times 10^{4}$ and $1.7 \times 10^{4} \mathrm{cfu} / \mathrm{g}$ in the first week of storage. A complete growth inhibition of gram negative bacteria was seen at $1.0 \mathrm{kGy}$ till the first week. The total viable bacterial count for that particular dose then progressed to $9.8 \times 10^{4} \mathrm{cfu} / \mathrm{g}$ after three weeks. The effects of all the treatments on total viable bacterial count vary significantly from each other at $\mathrm{p} \leq 0.05$.

\section{Enterobacteriaceae Identification through Analytical Profile Index 20 E}

The test results of API 20 E strips were analyzed on the basis of the color changes in the reaction. All the reactions were recorded on the laboratory report. The results were then compared with the identification table given in the manual provided along with the API 20E kit. The identified microorganism was Shigella sonnie and Escherichia coli observed on SS agar and non fermentor spp, and E.coli observed on MacConkey agar.

\section{Total viable fungal count}

\section{Enumeration and identification of fungi on potato dextrose agar}

The Figure $2 \mathrm{~d}$ shows the total viable fungal count of banana's kept at room temperature as affected by the different doses of gamma radiation. The data clearly showed that the fungal load of banana fruits was considerably higher than that seen for the total bacterial load on different nutrient media. The control fruits harbored the greatest fungal load with a total viable fungal count of $7.5 \times$ $10^{4} \mathrm{cfu} / \mathrm{g}$ on the $7^{\text {th }}$ day of storage. This further incremented to $28.6 \times 10^{4} \mathrm{cfu} / \mathrm{g}$ for the next seven days after which the control began to deteriorate. A significant reduction was deployed by the lower 
doses of $0.25 \mathrm{kGy}$ and $0.5 \mathrm{kGy}$. However, the most effective results were noted for the highest dose of $1.0 \mathrm{kGy}$. The initial total viable fungal counts of 5.5 $\times 10^{4}, 4.2 \times 10^{4}$ and $3.1 \times 10^{4} \mathrm{cfu} / \mathrm{g}$ were obtained for the doses of $0.5,0.75$ and $1.0 \mathrm{kGy}$ respectively. The count for the above doses increased to $31.2 \times$ $10^{4}, 29.7 \times 10^{4}$ and $24.9 \times 10^{9} \mathrm{cfu} / \mathrm{g}$ till the end of the third week. The effects of all the treatments on total viable fungal count vary significantly from each other at $p \leq 0.05$.Based on the macroscopic and microscopic characteristics, the dominant filamentous fungi to be identified were Aspergillus niger, Aspergillus flavus, Collotrichum musae, Fusarium oxysporum,Mucor spp, Lasiodiplodia theobromea and Rhizopus stolonifer.

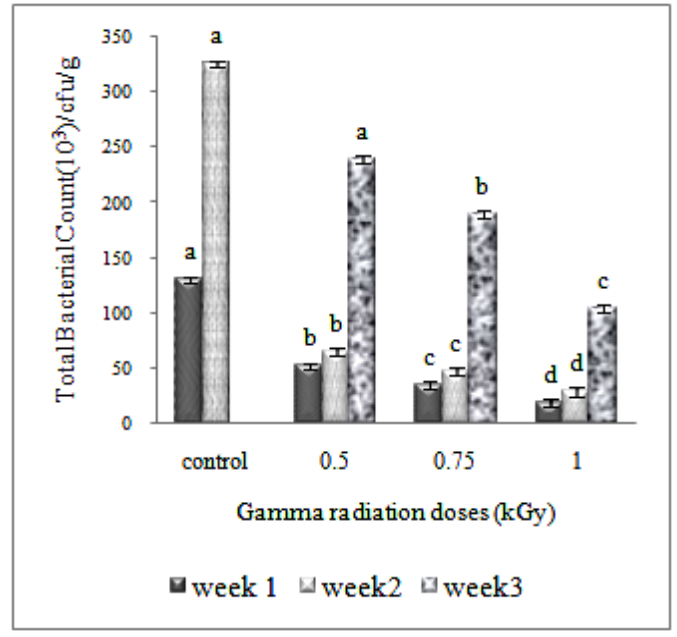

(a)

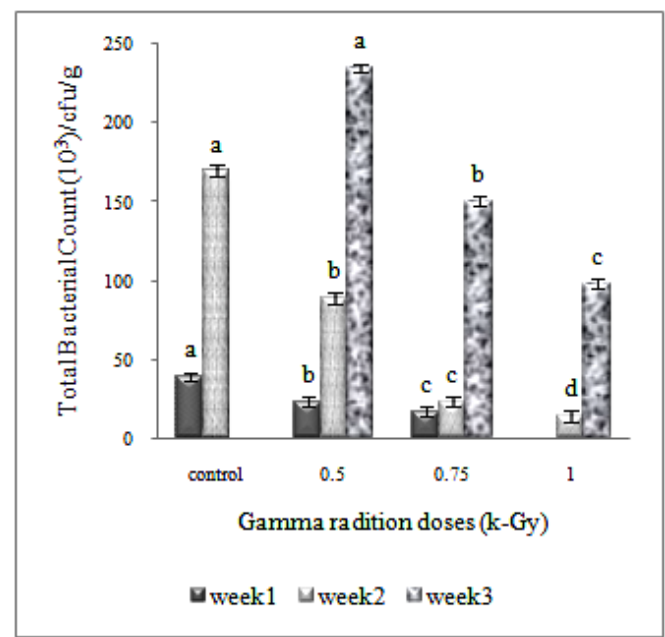

(c)

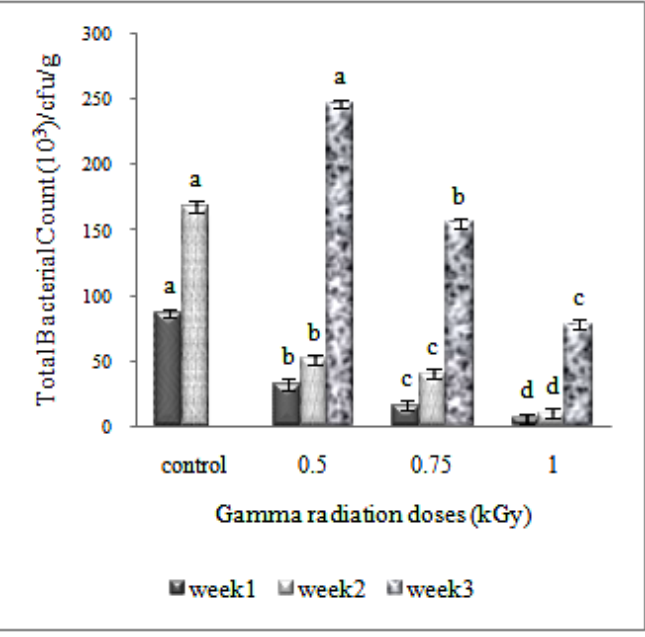

(b)

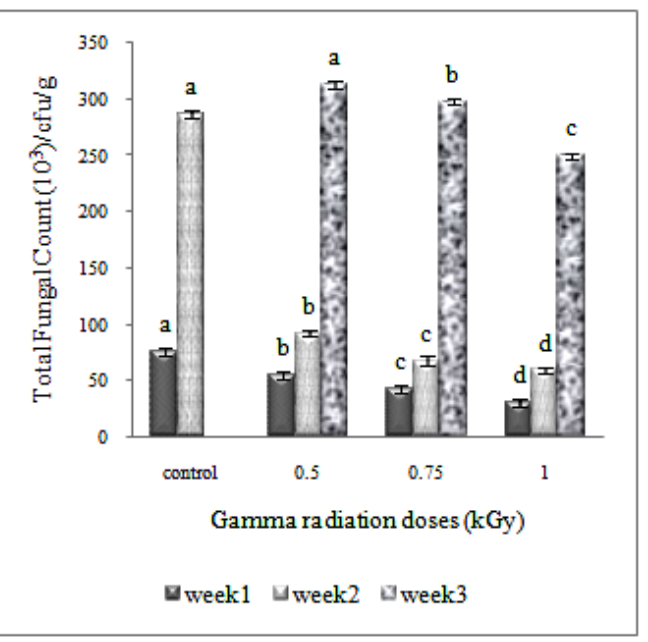

(d)

*Each value is the mean of five parallel replicates. The error bars indicate the standard deviation from the mean value. Superscripts indicate that the mean difference is significant at $\mathrm{p} \leq 0.05$ by Duncan's New Multiple Range Test.

Figure 2. Impact of different gamma radiation doses on total viable bacterial count on (a) nutrient agar (b) salmonella-shigella agar (c) MacCkoney agar (d) total fungal count on potato dextrose agar of bananas kept under ambient conditions

\section{DISCUSSION}

Gamma radiations have been proven to be energetically more powerful than the x-rays ( FAN and SOMMERS, 2012). In relation to that the unripe bananas in this study were exposed to gamma radiation doses of $0.5-1.0 \mathrm{kGy}$ and kept under ambient conditions. The effect of the different level of doses on epiphytic bacterial and fungal load, pulp to peel ratio, ripening period and decay percent of the fruits was analyzed and then compared to the controls which were also examined for the same parameters. Based on the decay percent analysis the treated fruits lasted longer than the control ones. 
The gamma radiation dose of $1.0 \mathrm{kGy}$ was the most suitable as compared to other doses in keeping the fruit safe from deterioration for the longest period of time under ambient conditions. It might be due to the fact that higher dose lead to higher sanitation efficiency thereby targeting more spoilage causing microorganisms ( SOMMERS et al., 2006).

All the levels of doses were effectual for enhancing shelf lives when compared to the control group. The changes in peel to pulp ratio and peel color index were used to monitor the ripening process in controls and treated fruits. The control bananas reached the full stage of ripening within 14 days while the gamma irradiated bananas receiving the highest dose of $1.0 \mathrm{kGy}$ ripened within 28 days. Therefore the shelf life of banana was extended by 14 days by gamma radiation treatment. The stage of the maturity of banana at which the irradiation is carried out also plays a vital role in determining the enhancement of the shelf life. Irradiation should be carried out as soon as possible after harvesting of bananas therefore the fruits in our experiment were given the radiation treatment within 12 hours after harvest. The irradiation of fruits for the purpose of delaying ripening must be carried out when the fruits are harvested at the hard mature green and before the start of climacteric phase. It was reported on account of Gloria and Adao ( 2013) who observed that irradiation at $1.0 \mathrm{kGy}$ at hard mature green stage of banana was the most appropriate dose in extending the shelf life to the longest period of time.

Bacterial pathogens cannot proliferate in fruits due to their low $\mathrm{pH}$ but they can survive for a sufficient time to cause foodborne disease ( JOSHI; PATEL, 2008). Occasional food-related illnesses caused by pathogens or bacterial toxins in fruits have been mostly attributed to contamination produced by exposure to human or animal waste or to contaminated irrigation water. In this study the contaminated microflora was Shigella sonnei and non fermented spp. identified with the help of analytical profile index $20 \mathrm{E}$ strips.

Control of food borne pathogens and shelf life extension can be acquired by the medium dose (1-10 kGy) application of ionizing radiation ( MILLER, 2006). In this regard the applied doses of gamma radiation worked well in reducing both the bacterial and fungal load in the present study. The bacterial load as analyzed on nutrient agar, salmonella-shigella agar and MacConkey agar showed a reduction in the case of irradiated fruits as compared to non irradiated ones. The halting effect of gamma radiation on microbial growth might be due to the reason that gamma radiation induces direct cell damage by having deleterious effects on the chromosomal DNA along with protein coagulation of living cells.( BARKAI-GOLAN, 2001). This effect was most profound with the samples irradiated at $1.0 \mathrm{kGy}$ in all the three different nutrient media. The epiphytic fungal and bacterial load of the fruits was recorded for three progressive weeks. The microbial load of both the control and irradiated fruits increased gradually with the passage of time giving highest records in the second week in case of controls and third week in case of irradiated samples after which the fruits in each group started showing symptoms of decay. This can be supported by GIHAN ( 2010) who examined the effect of gamma radiation on the microbial load of banana concluding that the treatment of gamma irradiation at all doses significantly reduced the load of yeast, mold and bacteria. Further, as the storage time increased, the microbial population increased. The fungal load of banana surface in this investigation also showed the same trend i.e the dose of $1.0 \mathrm{kGy}$ was the most effective dose in retarding the fungal growth of all the other treatments. Based on the macroscopic and microscopic characteristics, the dominant filamentous fungi to be identified were Aspergillus niger, Aspergillus flavus, Collotrichum musae, Fusarium oxysporum,Mucor spp, Lasiodiplodia theobromea and Rhizopus stolonifer. GAWAI ( 2011) and OYEWOLE ( 2012) also attributed the same fungal pathogen to the deterioration of banana fruits.

\section{ACKNOWLEDGEMENTS}

The authors are grateful to the authorities of Pakistan Radiation Services (PARAS) Foods Ltd, Lahore, Pakistan for providing the irradiation services during the entire course of the experiments.

RESUMO: O Presente estudo foi realizado para investigar os efeitos da radiação gama sobre a microflora epífita e amadurecimento das bananas Cavendish Anão verde colhidas no estádio de três quartos da maturidade. As bananas verdes maduros foram irradiadas usando Cobalto-60 como fonte de irradiação a diferentes dosagens de 0,5, 0,75 e 1,0 kGy. A vida média de ambos os grupos experimental e de controlo de frutas foi analisada sob as condições ambientes. Para todos os tratamentos a potenciais microbiana, o percentual decadência e do comportamento do amadurecimento dos frutos foram recorded.Results revelou que as doses de 
radiação aplicadas reduziu a incidência de podridões, atrasou processo de amadurecimento e inibir significativamente o crescimento microbiano (contagem de bactérias e fungos total), assim aumentar a vida de prateleira das bananas. dose de irradiação de 1,0 kGy foi encontrada como sendo a dose mais eficaz para manter positivamente as bananas armazenada sob condições ambientes. A vida média de bananas foi prorrogado por 14 dias. A identificação do bacteriaeaceae entérico através de API 20 E tiras revelou a presença de Shigella sonnie sobre a superfície do fruto, juntamente com Escherichia coli e um nonfermentor spp. A deterioração dominante causando fungos identificados foram Aspergillus niger, Aspergillus flavus, Collotrichum musae, Fusarium oxysporum, Mucor spp, Lasiodiplodia theobromea e Rhizopus stolonifer.

PALAVRAS-CHAVE: Banana. Irradiação gama. Microflora. Vida de Prateleira.

\section{REFRENCES}

BARKAI-GOLAN, E. Diseases postharvest fruits and vegetables: development and control. 1. ed. Amsterdam, 2001. p. 205-217

DIONÍSIO, A. P.; GOMES, R. T.; Oetterer, ionizing radiation effects on M. vitamins food: a review. Brazil Arch of Biol Technol, v. 52, n. 5, p. 1267-1278, 2009. https:/doi.org/10.1590/S1516-89132009000500026

FAN, X.; Sommers, C. H. Food irradiation research and technology. 2. ed. Oxford, 2012. p. 10-21.

FOLLETT, P. A .; WEINERT, E. D. comparative radiation dose mapping the type of single fruit and boxes of mixed fruits for export of Hawaii. J Food Process Preserv, v. 33, n. 2, p. 231-244, 2009.

https:/doi.org/10.1111/j.1745-4549.2008.00315.x

Gawai, S. S. biochemical changes in banana fruits due to postharvest fungal infections. Current Botany, V. 2, n. 1, p. 42-45, 2011.

GLORIA, M. B. A.; ADAM, R. C. Effect of gamma radiation on the maturation and levels of bioactive amines in banana cv. Silver. Radiat Phys Chem, v. 87, n. 5, p. 97-103, 2013.

https:/doi.org/10.1016/j.radphyschem.2013.02.032

HASSAN, M.; Shipton, W.; COVENTRY, R.; Gardiner, C. Extension of banana shelf life. Way Australas Plant, v. 33, n. 2, p. 305-308, 2004. https:/doi.org/10.1071/AP04011

JOSHI, P. A.; PATEL, microbiological S. P. Analysis of fresh fruit and vegetables and effect of antimicrobial agents in microbial load. 5. ed. New York, 2008. p. 123-156.

LIU, X .; Shiomi, S .; Nakatsuka, A .; Kubo, Y .; Nakamura, R .; Inaba A. Characterization of ethylene biosynthesis associated with banana fruit ripening. Plant Physiol, v. 121, n. 4, p. 1257-1265, 1999. https:/doi.org/10.1104/pp.121.4.1257

MASHAU, M.; Moyane, J.; JIDEANI, I. Evaluation of post-harvest fruit losses Tshakhuma fruit market in Limpopo Province, South Africa. Afr J Agric Res, v. 7, n. 29, p. 4145-4150, 2012.

https:/doi.org/10.5897/AJAR12.392

MILLER, R. B. Electronic irradiation of food: an introduction to technology. 1. ed. New York, 2006. p. 12-36.

MOHAMED, G. A.; MAHMOUD, G. A. Radiation Effects range in microbial load and chemical fruit Banana Constituents stored at different temperatures. Res J Agric Biol Sci, v. 6, n. 4, p. 431-442, 2010.

NELSON, S. C.; PLOETZ, R. C.; KEPLER, the species A. K. Musa (banana and plantain). Species profiles for Pacific Island Agro Forestry, v. 9, n. 22, p. 33-45, 2006. 
OYEWOLE, O. microorganisms associated with the deterioration of banana fruit stored. Front Sci, v. 2, n. 5, p. 86-91, 2012. https:/doi.org/10.5923/j.fs.20120205.01

POSTMASTER, A.; SIVASITHAMPARAM, K.; Turner, D. Enumeration and identification of microorganisms isolated from banana fruit surface in three stages of development. Sci Hortic, v. 69, n. 3, p. 189-197, 1997. https:/doi.org/10.1016/S0304-4238(96)00994-6

SOMMERS, C. H.; DELINCÉE, H.; SMITH, J. S.; MARCHIONI, E. Toxicological safety of irradiated foods. Food Res Technol Irrad, v. 1, n. 5, p. 43-61, 2006. https:/doi.org/10.1002/9780470277638.ch4

SURENDRANATHAN, K. Postharvest biotechnology fruit with special reference to banana - perspective and scope. Indian J Biotech, v. 4, n. 1, p. 39-46, 2005.

ZAMAN, W.; PAUL, D.; ALAM, K.; IBRAHIM, M .; HASSAN, P. Extending the shelf life of banana (Musa sapientum) by gamma radiation. J Bio Sci, v. 15, n. 3, p. 47-53, 2007. 